\title{
Gold Nanoparticles Synthesized with a Polyphenols-Rich Extract from Cornelian Cherry (Cornus mas) Fruits: Effects on Human Skin Cells
}

\author{
Maria Perde-Schrepler, ${ }^{1}$ Luminita David, ${ }^{2}$ Liliana Olenic, ${ }^{3}$ Monica Potara, ${ }^{4}$ \\ Eva Fischer-Fodor, ${ }^{1}$ Piroska Virag, ${ }^{1}$ Florica Imre-Lucaci, ${ }^{4}$ Ioana Brie, ${ }^{1}$ and Adrian Florea ${ }^{5}$ \\ 1 "Ion Chiricuta" Oncology Institute, 34-36 Republicii Street, 400015 Cluj-Napoca, Romania \\ ${ }^{2}$ Faculty of Chemistry and Chemical Engineering, Babes-Bolyai University, 11 Arany Janos Street, 400028 Cluj-Napoca, Romania \\ ${ }^{3}$ National Institute for Research and Development of Isotopic and Molecular Technologies, 65-103 Donath Street, \\ 400293 Cluj-Napoca, Romania \\ ${ }^{4}$ Nanobiophotonics and Laser Microspectroscopy Center, Interdisciplinary Research Institute on Bio-Nano-Sciences, \\ Babes-Bolyai University, 42 Treboniu Laurian Street, 400271 Cluj-Napoca, Romania \\ ${ }^{5}$ Department of Cell and Molecular Biology, Faculty of Medicine, "Iuliu Hatieganu" University of Medicine and Pharmacy, \\ 6 Louis Pasteur Street, 400349 Cluj-Napoca, Romania
}

Correspondence should be addressed to Maria Perde-Schrepler; pmariaida@yahoo.com

Received 15 March 2016; Revised 5 May 2016; Accepted 16 May 2016

Academic Editor: Andrea Falqui

Copyright (C) 2016 Maria Perde-Schrepler et al. This is an open access article distributed under the Creative Commons Attribution License, which permits unrestricted use, distribution, and reproduction in any medium, provided the original work is properly cited.

Gold nanoparticles (GNPs) were obtained by green synthesis with an extract from Cornus mas fruits (GNPs-CM), characterized by several methods, and their biologic effects were evaluated on two cell lines: HaCaT, normal keratinocytes, and A431, epidermoid carcinoma. GNPs were spherical with sizes between 2 and $24 \mathrm{~nm}$. Their optical spectra had a dominant plasmonic band centered at $525 \mathrm{~nm}$; zeta potential distribution was narrow, centered at $-19.7 \mathrm{mV}$, and the mean hydrodynamic diameter was $58 \mathrm{~nm}$. GNPs were visualized in both cell types entering the cells by endocytosis. The amount of gold uptaken by the cells was dose and time dependent. The intracellular concentration of Au ions was higher in HaCaT compared to A431 cells. The toxicity of GNPs-CM was dose dependent being significant only when the highest concentrations were employed. A431 cells were less affected compared to HaCaT cells, but the difference was not statistically significant. ROS production was not significant, except in HaCaT cells at the highest concentration. The comet assay revealed no significant supplementary DNA lesions, while the secretion of inflammatory cytokines was modulated by the presence of GNPs only when the cells were additionally irradiated with UVB. These results recommend GNPs-CM for further testing and possible dermatological applications.

\section{Introduction}

There is a growing interest for the synthesis of nanomaterials due to their wide applicability in many areas, including medicine and biology. Gold nanoparticles (GNPs) have been manufactured for drug delivery [1], imaging [2] (nanogold reflects light very well, characteristic called plasmon resonance), photothermal therapy [3], photodynamic therapy [4], cancer diagnosis and therapy $[5,6]$, and so forth.
GNPs synthesis is usually achieved by expensive methods having potential environmental and biological risks: chemical reduction, thermal deposition in organic solvents [7], chemical and photoreduction, electrochemical, sonochemical, and microwave assisted methods [8], and so forth. There is a need to develop environmental friendly processes such as the biomimetic synthesis (bioreduction), green synthesis using microorganisms, enzymes, fungi, or plants/plant extracts. The use of a biological source offers an easy and affordable 
approach and is becoming an important branch of nanotechnology. Plants represent an attractive solution for NPs synthesis because they contain reducing agents such as citric acid, ascorbic acid, flavonoids, reductases, and dehydrogenases, being able to reduce metals in physiological conditions. The biologically active molecules involved in the green synthesis of NPs act as functionalizing ligands, making these NPs more suitable for biomedical applications [9]. The main features making green synthesis so remarkable are rapid synthesis, low toxicity, and controlled size of the obtained nanoparticles, being also an economical and ecofriendly approach.

The purpose of this study was to obtain GNPs by green synthesis using an extract obtained from the fruits of Cornelian cherry (Cornus mas, CM) and to evaluate their in vitro biologic effect on normal and tumor skin cell lines.

Its abundance and low cost make Cornus mas plant extract attractive for the synthesis of metallic nanomaterials. So far, Cornelian cherry proved to have several beneficial biologic effects, such as antimicrobial and antihistaminic, both in vivo and in vitro [10], antioxidant in vitro [11], bactericide on Bacillus and E. coli in vitro [12], and antitumoral effects [13].

\section{Material and Methods}

2.1. Reagents. All chemicals and reagents used for the extract and nanoparticles preparation were of analytical grade, purchased from Merck, Germany, and used without further purification.

\subsection{Synthesis of Gold Nanoparticles}

2.2.1. Preparation of Cornus mas Extract. CM extract was obtained from crushed frozen fruits, mixed with double distilled water, and then filtered under vacuum. Total anthocyanin content (TAC) was $20 \mathrm{mg} / \mathrm{L}$ while total polyphenol content (TPC) was $240 \mathrm{mg} / \mathrm{L}$. The total anthocyanin content was determined using the $\mathrm{pH}$ differential method [14] and the total phenolic content was assessed by the Folin-Ciocalteu method [15].

2.2.2. Preparation of Gold Nanoparticles. $12.5 \mathrm{~mL}$ of CM extract was added to a vigorously stirred boiling solution containing $150 \mathrm{~mL}$ bidistilled water and $5 \mathrm{~mL} \mathrm{1 \%}$ chloroauric acid $\left(\mathrm{HAuCl}_{4}\right)$ solution. The mixture was continuously stirred for 10 -minute interval in which the reduction of gold ions took place and a red-purple color was obtained [16]. Before being analyzed, the nanomaterials were centrifuged at 15,000 rpm for 10 minutes and washed and resuspended in double distilled water. The colloids were stable for three weeks in solution (no aggregation was observed). Citrate-coated gold nanoparticles were obtained by the trisodium citrate reduction [17].

\subsection{Characterization of the Synthesized NPs}

2.3.1. The Morphology and Size. The morphology and size of GNPs were examined on a JEOL-JEM 1010 transmission electron microscope (TEM) (JEOL Ltd., Tokyo, Japan). The diameters of GNPs $(n=924)$ were measured on the TEM images using CellD software (Olympus Soft Imaging Solutions GMBH, Munster, Germany). The mean diameter value and standard deviations were calculated, and the size distribution was graphically represented with Microsoft Excel (Microsoft Corporation, Redmond, USA).

2.3.2. The Plasmon Absorption. The plasmon absorption of the biosynthesized GNPs was assessed by ultraviolet-visiblenear infrared (UV-Vis-NIR) extinction spectroscopy and the spectra were measured in a $2 \mathrm{~mm}$ quartz cell using a Jasco $\mathrm{V}$ 670 spectrometer (Jasco UK Ltd., Great Dunmow, Essex, UK) with $1 \mathrm{~nm}$ spectral resolution. We investigated the stability of GNPs under physiological conditions by incubating $500 \mu \mathrm{L}$ of colloidal suspension with $100 \mu \mathrm{L}$ of complete culture medium.

2.3.3. The Zeta Potential. The zeta potential of GNPs was determined by the laser Doppler microelectrophoresis technique using Malvern Zetasizer Nano ZS-90 (Malvern Instruments Ltd., Malvern, UK) with a He-Ne laser operating at $633 \mathrm{~nm}$ and an avalanche photodiode detector. The samples were diluted 1:5 with bidistilled water. The $\mathrm{pH}$ of the diluted colloidal gold nanoparticle solution was 6.8 .

2.3.4. The Hydrodynamic Size. The hydrodynamic size determines the size distribution of particles in liquid suspension by measuring the effects in light scattering due to the Brownian motion of the nanoparticles. It was measured using the same solution as that for the zeta potential with a Malvern Zetasizer based on dynamic light scattering (DLS) measurements at $90^{\circ}$. The particle size and zeta potential measurements were performed at $25^{\circ} \mathrm{C}$.

2.4. Cell Lines. The spontaneously immortalized human keratinocyte cell line HaCaT was purchased from the Cell Line Service of the German Cancer Research Centre in Heidelberg and maintained in high glucose Dulbecco's Modified Eagles' Medium (DMEM) supplemented with $10 \%$ heat inactivated fetal bovine serum (FBS), $2 \mathrm{mM}$ glutamine, $50 \mathrm{UI} / \mathrm{mL}$ penicillin, and $50 \mathrm{mg} / \mathrm{mL}$ streptomycin (all from Sigma-Aldrich, St. Louis, USA). A431 epidermoid carcinoma cell line was purchased from the European Collection of Cell Cultures (ECACC) and kept in Minimum Eagles' Medium (MEM) supplemented with $1 \%$ NEA, 10\% FBS, 2 mM glutamine, $50 \mathrm{UI} / \mathrm{mL}$ penicillin, and $50 \mathrm{mg} / \mathrm{mL}$ streptomycin (Sigma).

\subsection{Cellular Uptake}

2.5.1. Atomic Absorption Spectrometry. The cells were seeded on 6-well culture plates (Nunc, Thermo Fisher Scientific Waltham, USA) at a cellular density of $3 \times 10^{5}$ cells/well and exposed to two concentrations of GNPs-CM: $15 \mu \mathrm{g} / \mathrm{mL}$ and $6 \mu \mathrm{g} / \mathrm{mL}$, respectively. After 4,8 , and $24 \mathrm{~h}$ incubation, the cells were harvested by trypsinization, washed, and centrifuged twice. The cell pellets were weighed and kept frozen at $-80^{\circ} \mathrm{C}$. The incorporated $\mathrm{Au}$ atoms were quantified with an atomic absorption spectrometer (AAS, Model AVANTA PM) 
equipped with a graphite oven (GF3000) and a programmable autosampler (PAL3000) (GBC Scientific Equipment, Braeside, Australia). A cathodic Au lamp (P821 HCL) and a Deuterium lamp (P701) were used for the correction of the baseline and pyrolytic P301 graphite ovens (Photron PTY Ltd., Victoria, Australia). The operating parameters were as follows: intensity of $4.0 \mathrm{~mA}$, wavelength of $328.1 \mathrm{~nm}$, and $0.5 \mathrm{~nm}$ slit. Au standard solutions (LGC Standards $\mathrm{GmbH}$, Wesel, Germany) of $50 \mu \mathrm{g} / \mathrm{L}$ in $\mathrm{HCl} 2 \mathrm{~mol} / \mathrm{L}$ and the solubilized biological samples were injected in the oven. After drying at $85^{\circ} \mathrm{C}$ for $5 \mathrm{~s}$, at $95^{\circ} \mathrm{C}$ for $40 \mathrm{~s}$, and at $120^{\circ} \mathrm{C}$ for $10 \mathrm{~s}$, calcination at $400^{\circ} \mathrm{C}$ for $3 \mathrm{~s}$, and atomization at $2000^{\circ} \mathrm{C}$ for $3 \mathrm{~s}$, each sample and standard were measured three times, the final concentration representing their average. The results were expressed in $\mathrm{ng} \mathrm{Au} / \mathrm{mg}$ sample.

2.5.2. Transmission Electron Microscopy. HaCaT and A431 cells, both the control group and cells exposed to GNPs, were processed for TEM. They were fixed for $1.5 \mathrm{~h}$ with $2.7 \%$ glutaraldehyde (Electron Microscopy Sciences, Hatfield, USA), washed four times with $0.1 \mathrm{M}$ phosphate buffer ( $\mathrm{pH} 7.4$ ), postfixed for $1.5 \mathrm{~h}$ with $1.5 \%$ osmium tetroxide (Sigma-Aldrich, St. Louis, USA), dehydrated in acetone series, and embedded in Epon 812 resin (Fluka, Buchs, Switzerland). The ultrathin sections obtained with glass knives using a Bromma 8800 ULTRATOME III (LKB, Stockholm, Sweden) were collected on 300-mesh copper grids (Agar Scientific Ltd., Stansted, UK). For better visualization of the localization of NPs within the cells, the sections were contrasted for only $5 \mathrm{~min}$ with uranyl acetate (Merck, Billerica, USA). The samples were examined on a JEOL-JEM 1010 transmission electron microscope at $80 \mathrm{kV}$ acceleration voltage and photographed with a Mega VIEW III camera (Olympus, Soft Imaging System, Münster, Germany).

2.6. Cytotoxicity Assays. The cells were plated in 96-well plates (Nunc), at a density of $2 \times 10^{4}$ cells/well. The cultures were observed daily to document changes in cell morphology as a result of the treatment with NPs. Treatments were done with serial dilutions of NPs solutions, three wells for each concentration. For each experiment, cells from at least three wells were left untreated (control). Dilutions were made from the initial nanoparticle solution $(0.19 \mathrm{mg} / \mathrm{mL})$. The concentrations used in the experiments were $30,22,15,6,3$, $2.2,1.5$, and $0.6 \mu \mathrm{g} / \mathrm{mL}$. In order to compare the cytotoxicity of GNP-CM with that of citrate-coated gold nanoparticles (GNPs-C) synthesized by trisodium citrate reduction, the same concentrations (as specified above) of GNP-C were used on HaCaT cells. For both kinds of nanoparticles, after $24 \mathrm{~h}$ incubation, cell viability was assessed by Cell Titer Blue assay (Promega Corporation, Madison, USA), a fluorometric method using the indicator dye resazurin to measure the metabolic capacity of the cells. Viable cells retain the ability to reduce resazurin (dark blue) into resorufin, which is pink and highly fluorescent. Fluorescence was read on a Biotek Synergy 2 microplate reader (BioTek Instruments Inc., Winooski, USA), at $579 \mathrm{~nm}$ excitation and $584 \mathrm{~nm}$ emission. At each concentration, the surviving fraction was calculated as fluorescence of the sample/fluorescence of control (nontreated cells) $\times 100$. Each experiment was repeated 3 times.

2.7. Detection of Reactive Oxygen Species (ROS). The levels of ROS produced in the treated cells after treatment with GNPs-CM were assessed using the 5-(and-6)-chloromethyl$2^{\prime}, 7^{\prime}$-dichlordihydrofluorescein diacetate, acetyl ester-CM$\mathrm{H}_{2}$ DCFDA assay. CM- $\mathrm{H}_{2}$ DCFDA is a lipophilic compound which is deacetylated in the cytoplasm to DCF by the cellular esterases and subsequently oxidized by free radicals (hydroxyl, peroxyl, alkoxyl, nitrate, carbonate, etc.) to a fluorescent molecule (excitation $485 \mathrm{~nm}$, emission $530 \mathrm{~nm}$ ). $\mathrm{HaCaT}$ and A431 cells were seeded in 96-well plates (Nunc) at a cellular density of $2 \times 10^{4}$ cells/well and incubated with GNPs-CM: 15,6 , and $3 \mu \mathrm{g} / \mathrm{mL}$ for 4,8 , and $24 \mathrm{~h}$, respectively. After these intervals, the cells were washed and loaded with $20 \mu \mathrm{M}$ DCFH-DA in HBSS for 30 min. After washing, fluorescence was recorded with a Biotek Synergy 2 microplate reader.

2.8. Comet Assay. Comet assay (single-cell gel-electrophoresis assay) assessing the DNA lesions caused by GNPs-CM was performed using Tice's protocol with minor modifications $[18,19]$. The cells were plated on 6-well culture plates (Nunc). At 24 and $48 \mathrm{~h}$ after treatment with $15 \mu \mathrm{g} / \mathrm{mL}$ and $6 \mu \mathrm{g} / \mathrm{mL}$ GNPs-CM, the cells were trypsinized, mixed with $1 \%$ solution of low-melting-point agarose (LMA), and layered on microscope slides previously covered with normal-melting-point agarose (NMPA). The slides were kept in lysis solution at $4^{\circ} \mathrm{C}$ in the dark for $24 \mathrm{~h}$. After lysis, the slides were exposed to the alkaline buffer $(\mathrm{pH}>13)$ for 20 min for DNA unwinding. A uniform electric field of $1 \mathrm{~V} / \mathrm{cm}$ was then applied for 20 minutes. After neutralization and fixation, slides were stained with ethidium bromide. Comet scoring was performed visually, using a fluorescent Nikon E600 microscope (excitation filter $510-560 \mathrm{~nm}$, detection filter $590 \mathrm{~nm}, 400 \mathrm{x}$ magnification). The comets were classified into five categories: class 0 (undamaged cells, "comets" with no or barely detectable tails) and classes 1-4 ("comets" with increasing tail lengths). A minimum of 200 cells per sample were evaluated and grouped in 5 categories according to the amount of DNA in the tail: group A (no damage) $<5 \%$, group B (low damage) $5-20 \%$, group C (medium damage) $20-40 \%$, group D (high damage) $40-95 \%$, and group E (total damage) $>95 \%$. For each sample, the tail factor (TF) was calculated using Collins' formula and expressed in percents:

$$
\mathrm{TF}[\%]=\frac{\mathrm{A} \cdot F_{\mathrm{A}}+\mathrm{B} \cdot F_{\mathrm{B}}+\mathrm{C} \cdot F_{\mathrm{C}}+\mathrm{D} \cdot F_{\mathrm{D}}+\mathrm{E} \cdot F_{\mathrm{E}}}{200},
$$

where $\mathrm{A} \cdots \mathrm{E}$ are number of cells in a certain group and $F_{\mathrm{A}} \cdots F_{\mathrm{E}}$ are the relative percent of DNA in the tail.

2.9. Inflammation Assay. HaCaT cells were seeded on 24well plates (Nunc). Two plates were used, both being treated with $6 \mu \mathrm{g} / \mathrm{mL}$ gold nanoparticles. One plate was kept in dark, while the other one was exposed to UVB for the induction of inflammation in the keratinocytes. Irradiation was performed in the culture plates, without lids, using a broadband 
UVB source-Waldmann UV 181 (Waldmann GmbH, Germany). The emitted dose was measured with a Variocontrol radiometer (Waldmann GmbH, Germany). The exposure dose was calculated using the formula, dose $\left(\mathrm{mJ} / \mathrm{cm}^{2}\right)=$ exposure time $(\mathrm{sec}) \times$ intensity $\left(\mathrm{mW} / \mathrm{cm}^{2}\right)$, and was $100 \mathrm{~mJ} / \mathrm{cm}^{2}$. At 24 and $48 \mathrm{~h}$ after irradiation the supernatants were collected and the inflammatory cytokines IL- $1 \alpha$, TNF- $\alpha$, and IL-6 were assessed by ELISA, using Quantikine kits from R\&D (R\&D Systems Inc. Minneapolis, USA), following the manufacturers' protocol. Absorbance was read on a Tecan Sunrise reader (Tecan Group, Mannedorf, Switzerland). The corresponding concentrations were obtained based on the standard absorption curve using the Magellan 3 data analysis software (Tecan).

2.10. Statistical Analysis. The obtained data were analyzed using GraphPad Prism Software, version 5.0 (GraphPad Software, Inc., La Jolla, USA). Comparisons among multiple groups were done using two-way ANOVA with Bonferroni posttest. All values in text and in figures are expressed as mean \pm standard deviation, with a limit of statistical significance of $p<0.05$.

\section{Results}

\subsection{Characterization of GNPs-CM}

3.1.1. Morphology and Size. In the TEM, the gold nanoparticles synthesized with Cornus mas extract were round/oval in shape and had a heterogeneous size distribution (Figure 1(a)). The calculated mean diameter of GNPs-CM was $12.079 \pm$ $3.588 \mathrm{~nm}$, ranging from 2 to $24 \mathrm{~nm}$ as shown in the histogram in Figure 1(b).

3.1.2. Plasmon Absorption. Figure 2 shows the normalized UV-Vis-NIR extinction spectra of the resulted colloidal solution collected at the end of the reaction. For comparison, the normalized absorption spectrum of the aqueous solution of $\mathrm{CM}$ extract is also shown (Figure 2(a)). The optical spectra of the final product exhibited a dominant plasmonic band centered at $525 \mathrm{~nm}$ for GNPs-CM. The absorption spectrum of gold nanoparticles in the presence of cellular medium revealed no aggregation after $4 \mathrm{~h}$ of incubation (Figure 2(b)). However, a $3 \mathrm{~nm}$ red shift of the dipolar plasmon band occurred after the addition of cellular medium, indicating an increase in the local refractive index due to the adsorption of serum proteins onto the nanoparticles surface.

3.1.3. Zeta Potential. As seen in Figure 3(a), the zeta potential distribution of GNPs-CM was relatively narrow and centered at $-19.7 \mathrm{mV}$ for, indicating a good stability in colloidal suspension.

3.1.4. Mean Hydrodynamic Diameter of GNPs-CM by DLS. As DLS gave the mean hydrodynamic diameter of the nanoparticles, these values were somewhat larger than those measured by TEM images since the surface capping agents were also included. The DLS measurements (Figure 3(b))

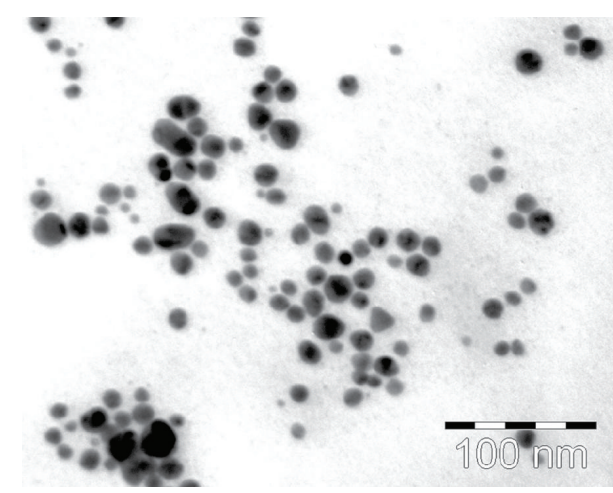

(a)

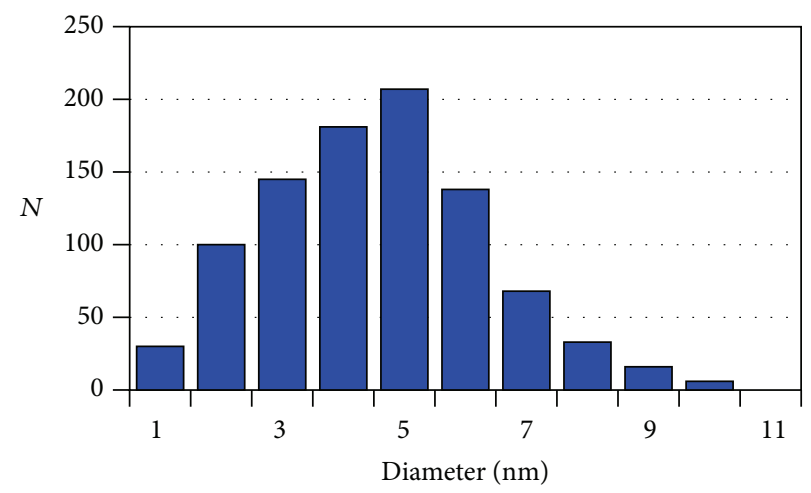

(b)

FIGURE 1: Characterization of GNPs-CM: (a) TEM image of GNPsCM. (b) Histogram showing the distribution of GNPs diameters ( $N=$ number of particles).

revealed a mean hydrodynamic diameter of $58 \mathrm{~nm}$ for GNPs$\mathrm{CM}$ confirming the presence of a stabilizing layer around the particles.

\subsection{Cellular Uptake}

3.2.1. Atomic Absorption Spectrometry. Au ions could be detected in all the samples treated with GNPs-CM as soon as $4 \mathrm{~h}$ after the treatment. Their concentrations increased proportionally with the NPs concentrations and incubation time, reaching the maximum at the $24 \mathrm{~h}$ time point. The intracellular concentration of $\mathrm{Au}$ ions after $24 \mathrm{~h}$ incubation with $15 \mu \mathrm{g} / \mathrm{mL}$ NPs was higher in the HaCaT cells compared to A431 cells, the difference being statistically significant ( $p<$ 0.001 , two-way ANOVA, Bonferroni posttest) (Figure 4).

3.2.2. TEM. Control HaCaT cells (Figure 5(a)) showed euchromatic nuclei with prominent nucleoli, many cell organelles (numerous mitochondria and several profiles of endoplasmic reticulum), and important amounts of glycogen; few lipid droplets were also found in the cells. All these indicated a sustained metabolic activity. The cells also displayed high number of short and thin extensions on their surface. TEM examination of cells after $24 \mathrm{~h}$ incubation with $15 \mu \mathrm{g} / \mathrm{mL}$ GNPs-CM showed that the GNPs entered the cells by endocytosis. They could be seen packed in small vesicles, sometimes 


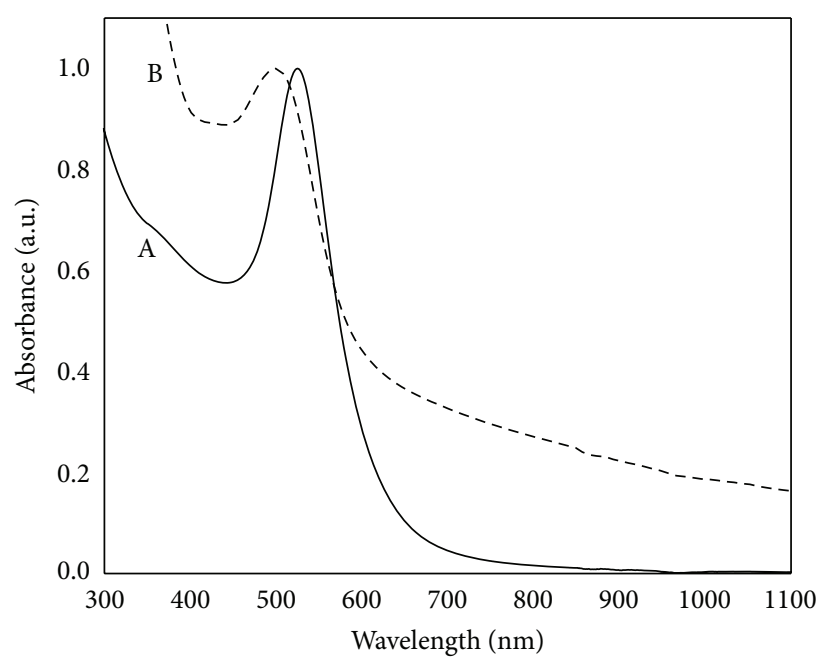

(a)

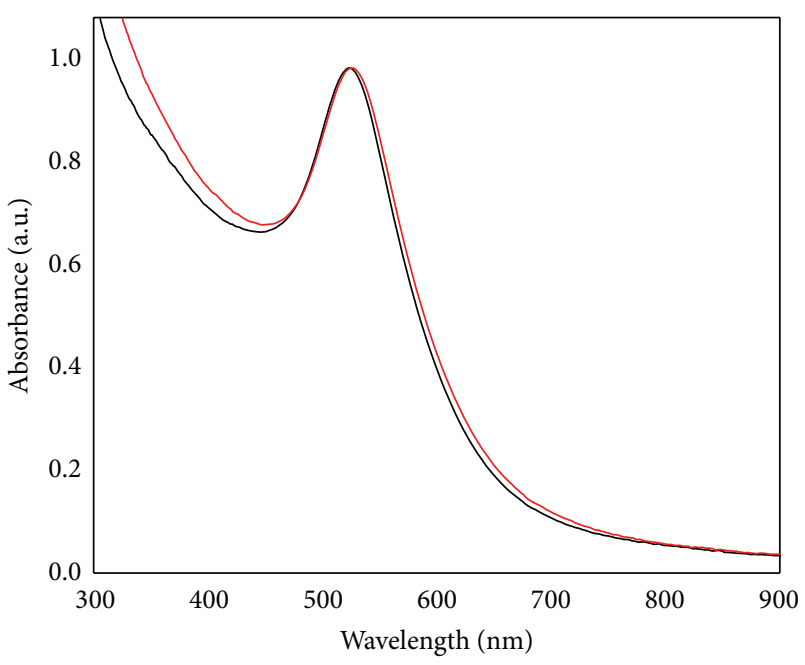

(b)

FIgURE 2: (a) Normalized extinction spectra of biosynthesized nanoparticles: (A) gold nanoparticles; (B) normalized UV-Vis absorption spectrum of the aqueous solution of Cornus mas (CM) extract. (b) Normalized UV-Vis absorption spectra of colloidal gold nanoparticles: before (black curve) and after the addition of cellular medium without phenol red (red curve). The spectra were recorded after $4 \mathrm{~h}$ of incubation.

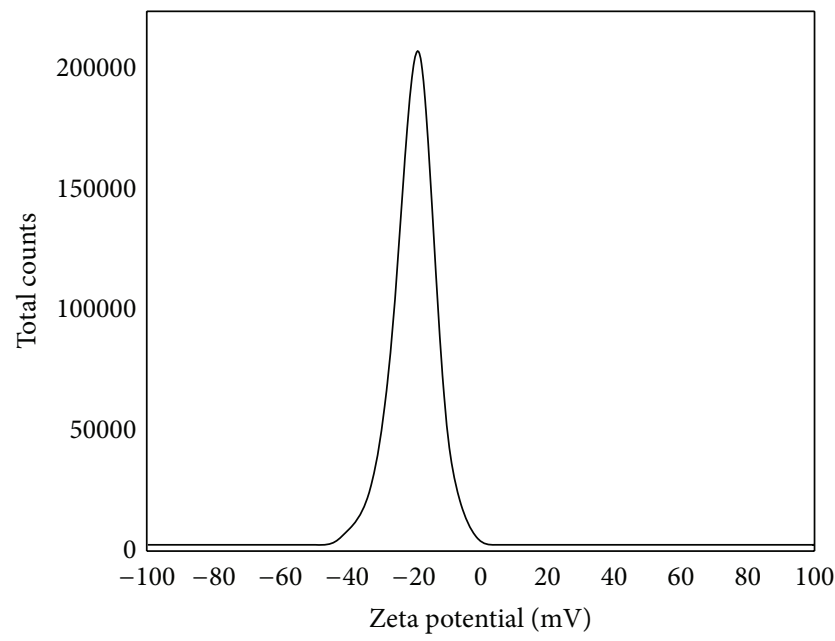

(a)

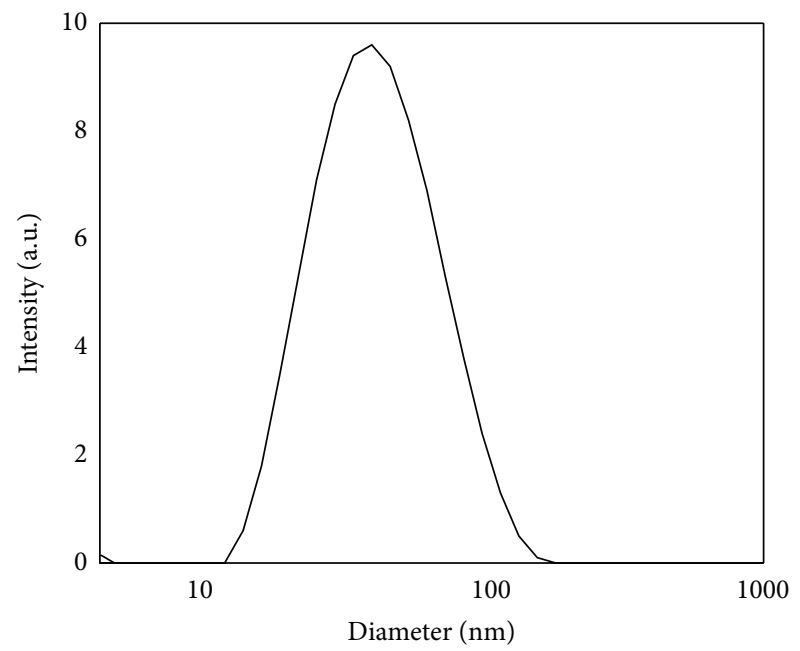

(b)

Figure 3: (a) Surface charge distribution of GNPs-CM by $\zeta$-potential measurements. (b) Size distributions of GNPs-CM by DLS measurements.

even in the proximity of the nucleus (Figure 5(b)), but the majority were observed free in the cytosol, still aggregated in clusters, in different regions of the cells (Figure 5(c)). The A431 control cells had thinner and fewer extensions, large and euchromatic nuclei with prominent nucleoli, altogether indicating a high metabolic activity. The cytoplasm had reduced number of cell organelles and a low amount of glycogen (Figure 5(d)), as a result of shorter cell cycles in this line which is a tumor cell line. In these cells, we could not find on the examined sections the GNPs packed in vesicles inside the cytoplasm (as in the case of HaCaT cells) (Figure 5(e)). These GNP clusters were also observed deep inside the cytoplasm, even next to the nucleus (Figure 5(f)). In both cases we measured inside the cells GNPs of various sizes (data not shown), including large particles, of around $20 \mathrm{~nm}$, suggesting that there was no size limitation in the endocytosis process.

3.3. Cytotoxicity Assay. When GNPs-CM were added in the culture medium, the viability of both cell lines decreased dose-dependently (Figure 6(a)). The cytotoxic effect was significant at doses higher than $20 \mu \mathrm{g} / \mathrm{mL}$. The cytotoxic effect was higher in HaCaT cells compared to the other cell line, in accordance with the higher uptake in these cells after $24 \mathrm{~h}$ incubation. The concentrations which reduced the cell population by $50 \%$ (IC50) were $23.9 \mu \mathrm{g} / \mathrm{mL}$ for $\mathrm{HaCaT}$ cells and 


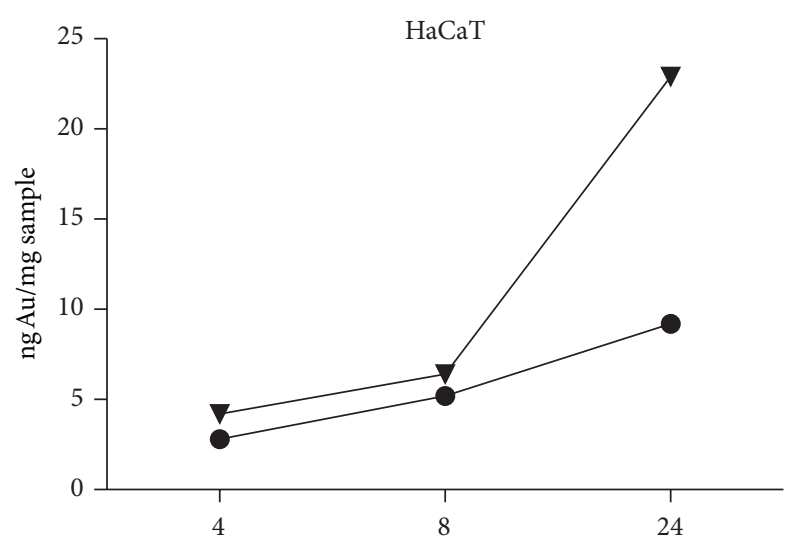

(h)

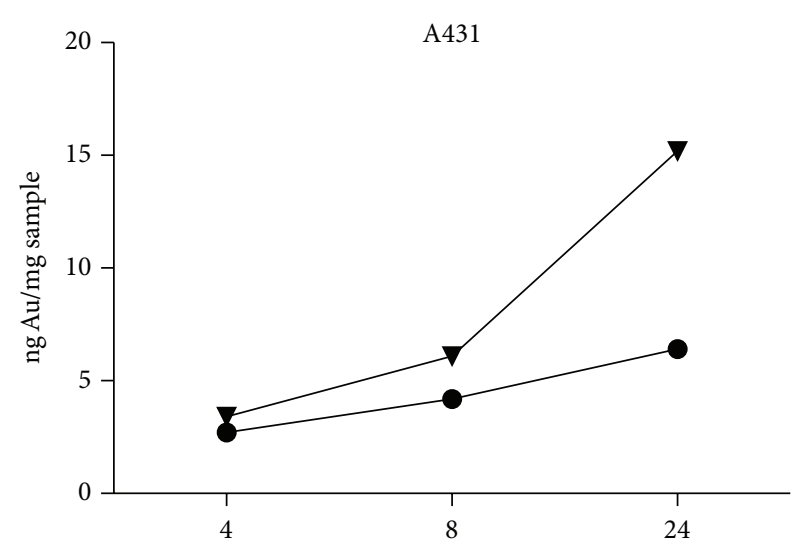

(h)

(a)

(b)

FIgURE 4: The concentration of Au ions in the keratinocytes as function of dose and time in HaCaT and A431 cells. $\mathbf{\nabla}$ : GNPs-CM $15 \mu \mathrm{g} / \mathrm{mL}$. ๑: GNPs-CM $6 \mu \mathrm{g} / \mathrm{mL}$.

$28.19 \mu \mathrm{g} / \mathrm{mL}$ for A431 cells. The differences in the cytotoxicity of GNPs towards the two cell lines were significant only at concentrations above $15 \mu \mathrm{g} / \mathrm{mL}$ (two-way ANOVA). The cytotoxicity of GNPs-CM obtained by us using an ecofriendly method was compared to that of citrate-coated GNPs (GNPsC) synthesized by trisodium citrate reduction. The toxicity of the NPs synthesized with $\mathrm{CM}$ extract on $\mathrm{HaCaT}$ keratinocytes was significantly lower than that of GNPs-C, at concentrations higher than $1.5 \mu \mathrm{g} / \mathrm{mL}(p<0.001)$ (Figure 6(b)).

3.4. ROS Production. We assessed the production of ROS in both cell lines following the treatment with 3 concentrations of GNPs-CM at 3 different time points: 4,8 , and $24 \mathrm{~h}$, respectively. In $\mathrm{HaCaT}$ cells after $8 \mathrm{~h}$ incubation with the highest concentration of NPs there was a significant increase in ROS $(p<0.001$, two-way ANOVA), but this difference could not be observed after $24 \mathrm{~h}$ (Figure 7(a)). GNPs-CM did not induce significant ROS production in the A431 cells compared to control cells (Figure 7(b)).

3.5. Comet Assay. As shown in Figure 8(a), GNPs-CM added to the culture medium of $\mathrm{HaCaT}$ cells in two concentrations, $15 \mu \mathrm{g} / \mathrm{mL}$ and $6 \mu \mathrm{g} / \mathrm{mL}$, did not induce significant supplementary DNA lesions compared to the nontreated cells, at neither of concentrations and time points ( 24 and $48 \mathrm{~h}$ ). In the A431 cells, DNA lesions were slightly but not significantly increased after $24 \mathrm{~h}$, at both concentrations; these lesions were repaired at $48 \mathrm{~h}$, showing no differences compared to the control cells (Figure 8(b)).

3.6. Inflammation Assay. The assessment of inflammatory cytokines in the culture medium of $\mathrm{HaCaT}$ cell line treated with GNPs-CM came with the following results: when the nanoparticles were added in the culture medium of $\mathrm{HaCaT}$ cells, they caused no significant modification of the IL- $1 \alpha$, TNF- $\alpha$, and IL- 6 levels, at neither incubation interval: 6,12 , and $24 \mathrm{~h}$ (Figures 9(a), 9(b), and 9(c), dark). The irradiation of $\mathrm{HaCaT}$ cells with $100 \mathrm{~mJ} / \mathrm{cm}^{2}$ UVB led to a reduction of IL$1 \alpha$ levels in the supernatants after $6 \mathrm{~h}$, followed by a gradual increase at $12 \mathrm{~h}$, reaching the same level as in control cells at $24 \mathrm{~h}$. TNF- $\alpha$ levels increased significantly $12 \mathrm{~h}$ after UVB exposure, while at 6 and $24 \mathrm{~h}$ the concentrations were similar to the control cells. IL- 6 levels increased also at the $12 \mathrm{~h}$ time point and were still slightly higher compared to the nonirradiated cells at $24 \mathrm{~h}$. When the cells were treated with GMPsCM before UVB irradiation, for IL- $1 \alpha$, the presence of GNPs$\mathrm{CM}$ had no impact on the IL- $1 \alpha$ release: the concentration of the cytokine was similar in control cells and cells treated with NP, in both the unexposed and irradiated cells (Figure 9(a), UVB). For TNF- $\alpha$, GNPs-CM inhibited the release of higher amounts at $12 \mathrm{~h}$ after irradiation (Figure 9(b), UVB). On the contrary, GNPs-CM led to a higher amount of IL-6 in the supernatants after UVB at all the tested intervals compared to the cells irradiated only (no NPs) (Figure 9(c), UVB).

\section{Discussions}

Noble metal nanoparticles attract much interest because of their special optical and photothermal properties resulting from the resonant oscillation of their free electrons in the presence of light, known as localized surface plasmon resonance. Thus they can either radiate light (scattering) or absorb light converting it to heat [20]. Due to the fact that a large number of gold nanoparticles are directed to the skin, evaluating the consequences of dermal exposure is crucial. Despite their demonstrated positive qualities, the potential detrimental effects on the treated subjects' health require caution and further assessment to ensure their safe use.

NPs have multiple applications in dermatology being used as photoprotectors, delivery systems for several active ingredients in both cosmetics and inflammatory diseases, photothermal therapy, photodynamic therapy, and so forth [21]. This is why it is important to study the effects of such nanoparticles on skin cells. In order to evaluate if a newly synthesized nanoparticle could have certain toxicities in 


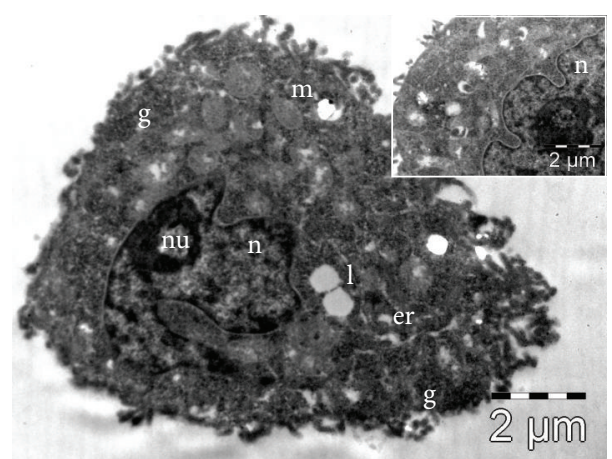

(a)

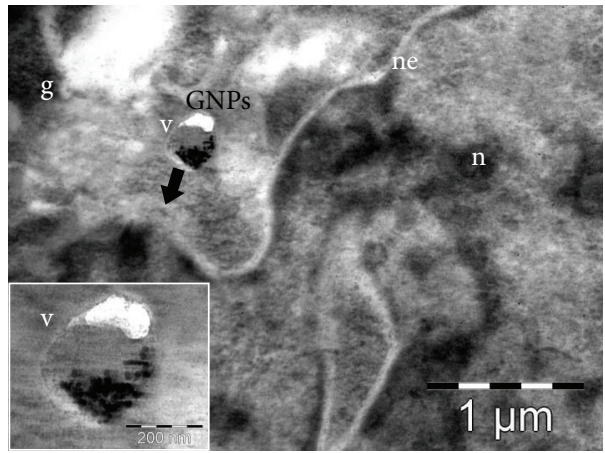

(b)

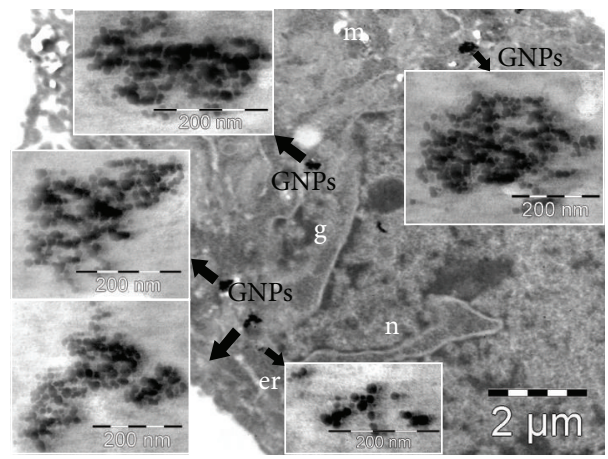

(c)

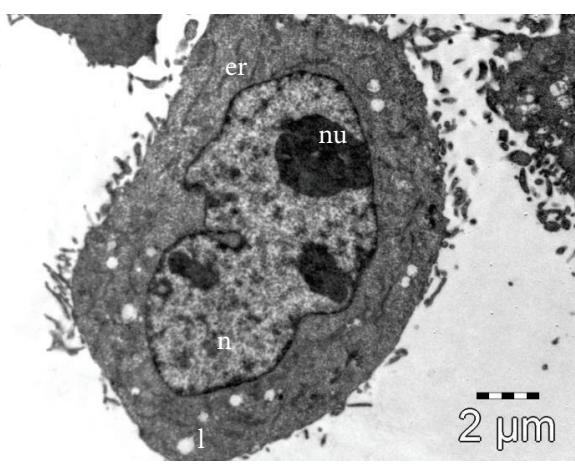

(d)

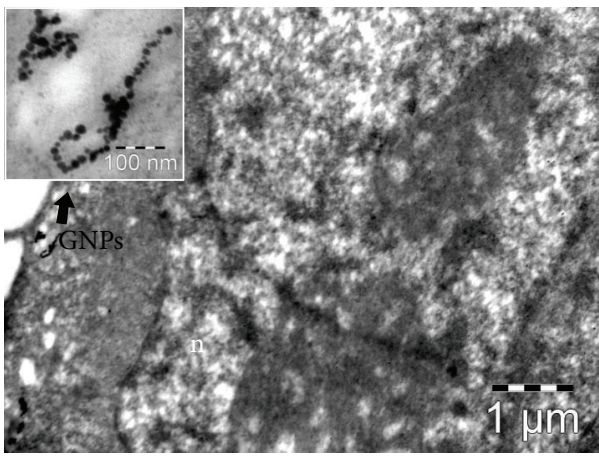

(e)

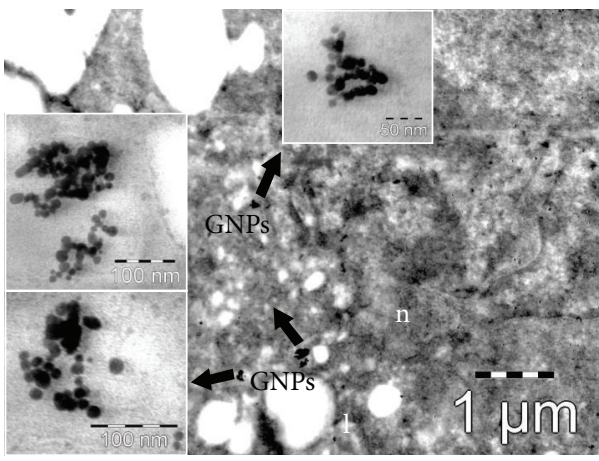

(f)

FIgURE 5: TEM images of keratinocytes from two lines: normal cells, HaCaT (a-c), and malignant cells, A431 (d-f). (a) Control HaCaT cell with normal ultrastructure. (b) Cytoplasmic localization of gold nanoparticles (GNPs) in small vesicles (v). (c) Cytoplasmic localization of GNPs as clusters in cytosol. (d) Epidermoid carcinoma cell with modified ultrastructure. (e) Cytoplasmic localization of GNPs in the proximity of plasma membrane. (f) Cytoplasmic localization of GNPs as clusters deeper inside the cell. n: nucleus; nu: nucleolus; m: mitochondria; er: endoplasmic reticulum; g: glycogen granules; 1: lipid droplets; ne: nuclear envelope.

biological settings, it is important to investigate the NPs physicochemical characteristics. NPs differ from other small molecules or chemicals in size, shape, surface charge, aggregation/agglomeration, solubility, interactions with media, and so forth [22]. The recent literature contains conflicting data concerning the cytotoxicity of gold nanoparticles. It is generally accepted that the cellular response after the administration of nanoparticles is size and shape dependent, as well as cell type dependent [23].

We synthesized GNPs using a green synthesis method with a natural extract from Cornus mas fruits. The obtained GNPs had a mean diameter of $12.079 \pm 3.588 \mathrm{~nm}$, were mostly round in shape, and had optical spectra with a dominant plasmonic band centered at $525 \mathrm{~nm}$ which represents the typical signature of the dipolar plasmon resonance of individual spherical GNPs [24]. An important condition for the use of metal nanoparticles in biomedical applications is their stability in physiological conditions. Herein, we investigated the stability of gold nanoparticles under physiological conditions in vitro by incubating the NPs suspension with complete cellular medium with and without phenol red. The reason was that the medium composition might affect particle aggregation which in turn would influence the endocytic pathway and thus the cellular fate of the NPs [25]. As seen on 


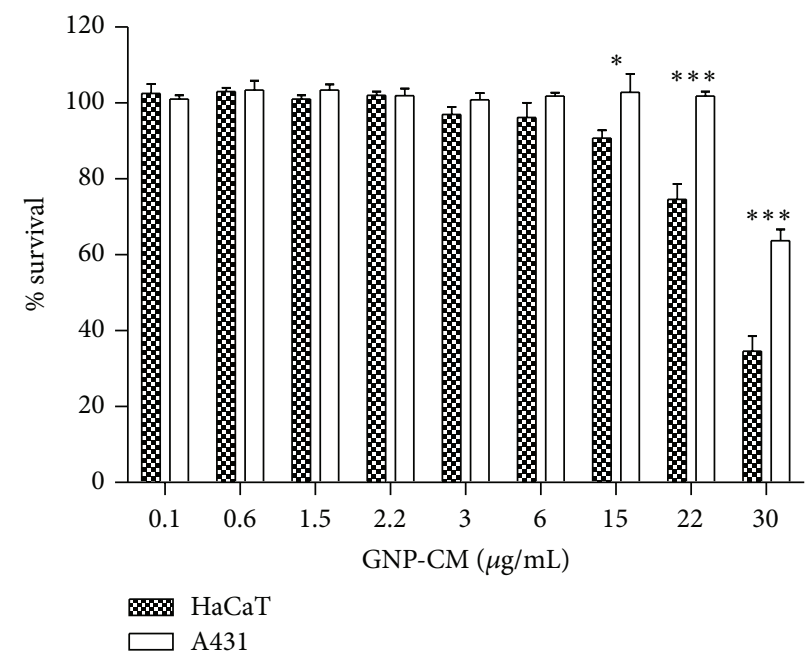

(a)

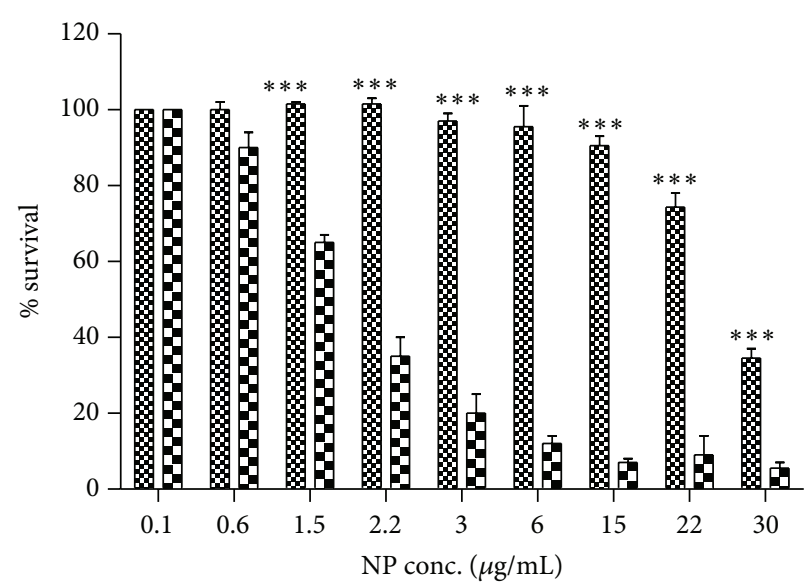

Q GNPs-CM
EN GNP-C

(b)

FIGURE 6: (a) Linear regression curve showing the decrease of the viability of keratinocytes depending on the NPs concentration. A431 cell line is showing an increased resistance to the toxicity of GNPs compared to HaCaT cells. The differences in the cytotoxicity of GNPs towards the two cell lines were significant only at concentrations above $15 \mu \mathrm{g} / \mathrm{mL}$ (two-way ANOVA) ${ }^{*} p<0.05$; (b) comparison of the cytotoxic effect of GNPs-CM with citrate coated GNPs (GNPs-C) on HaCaT cells, by two-way ANOVA and Bonferroni posttest ${ }^{* * *} p<0.0001$.

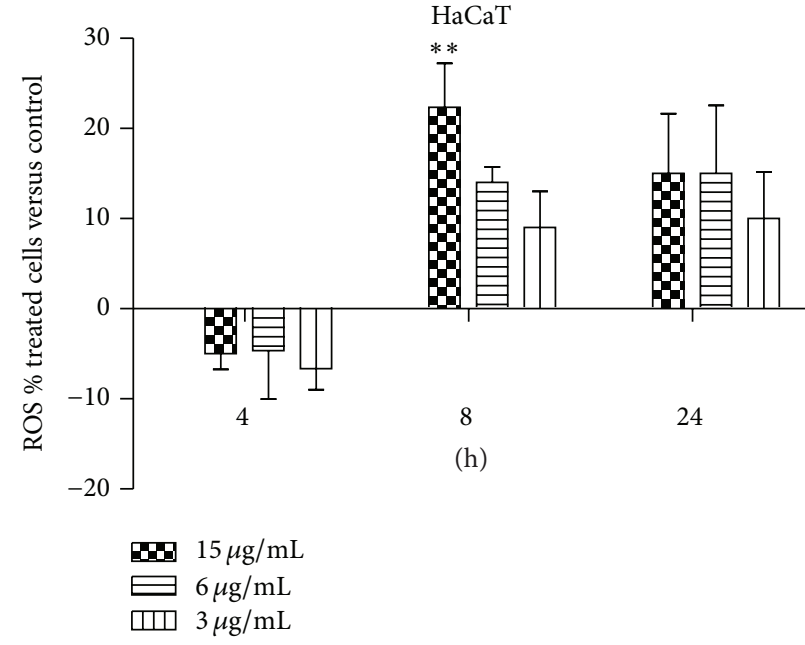

(a)

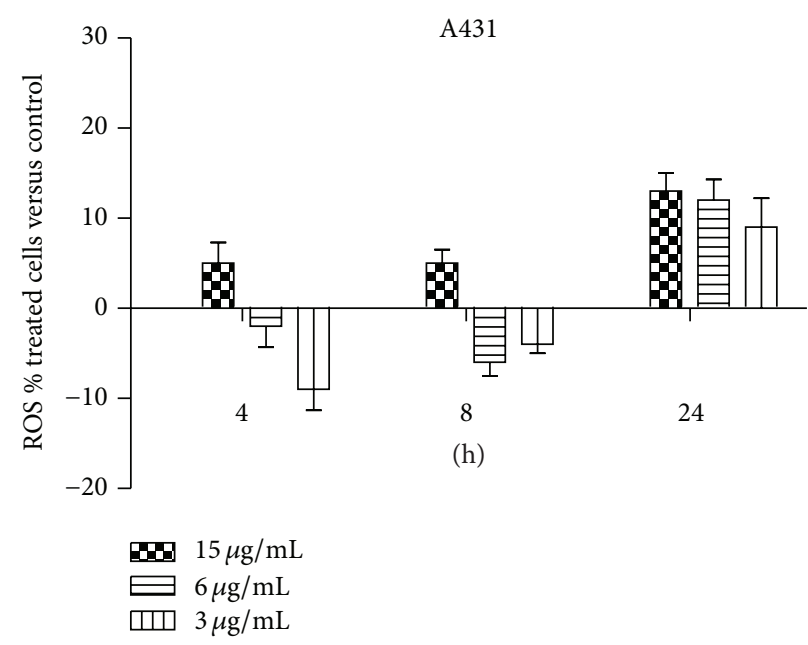

(b)

FIGURE 7: ROS production in HaCaT cells (a) and A431 cells (b) at different time points after treatment with increasing concentrations of GNPs-CM $(3,6$, and $15 \mu \mathrm{g} / \mathrm{mL})$ compared to control, nontreated cells. Nanoparticles induce significant ROS production at $8 \mathrm{~h}$ incubation with the highest concentration of gold NPs $(15 \mu \mathrm{g} / \mathrm{mL})$ in HaCaT cells $(p<0.001$, two-way ANOVA, Bonferroni posttest).

their absorption spectrum, GNPs-CM were stable in solution, as well as in the culture media of the cells, showing no aggregation. The stability of nanoparticles in a colloidal solution is defined in terms of the charge on their surface. The measured zeta potential and hydrodynamic diameter were additional proofs of GNPs-CM stability. DLS measurements giving a mean hydrodynamic diameter of $58 \mathrm{~nm}$ for GNPs-CM confirmed the presence of a stabilizing layer around the particles. GNPs are hydrophobic and the serum proteins present in the media are adsorbed on their surface, preventing aggregation which could impair the uptake mechanism of the NPs in the cells [25]. Media composition influences the formation of protein-NP complexes that may affect the cellular response [26]. Cellular uptake of GNPs-CM was dose and time dependent as assessed by atomic absorption spectrometry, showing a higher concentration in the HaCaT cells compared to A431 cells. This is an additional proof in favor of the hypothesis that uptake is cell type dependent as was the conclusion of Patra et al. who found that toxicity of gold nanoparticles was relative to the cell lines they were applied to [27]. This fact could be also explained by the different culture media used for the in vitro growth of the two cell lines. HaCaT cells are 


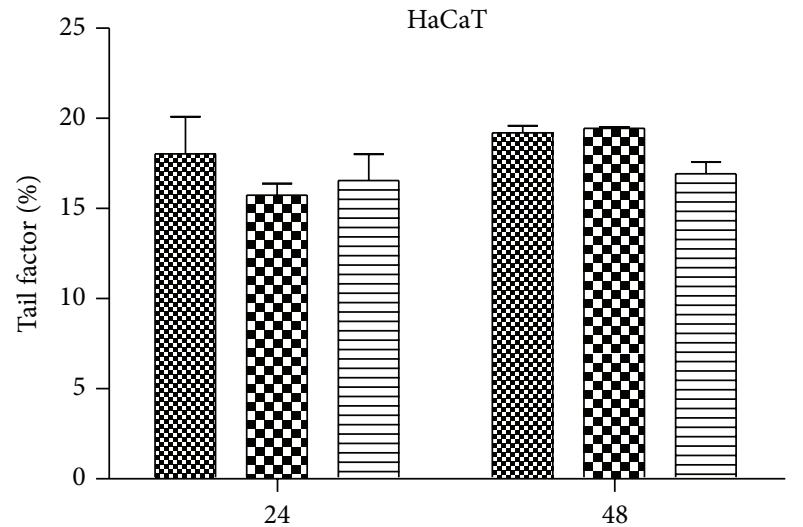

(h)

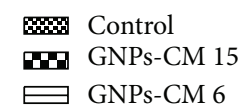

(a)

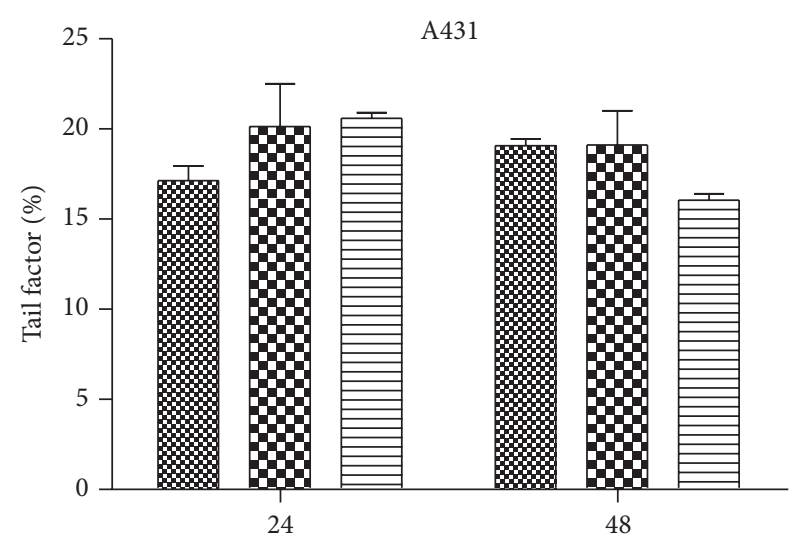

(h)
Control
GNPs-CM 15
GNPs-CM 6

(b)

Figure 8: DNA lesions expressed as tail factors (TF) recorded at $24 \mathrm{~h}$ and $48 \mathrm{~h}$ in HaCaT cells (a) and A431 cells (b) without any treatment (control) and after treatment with $15 \mu \mathrm{g} / \mathrm{mL}$ and $6 \mu \mathrm{g} / \mathrm{mL}$ of GNPs-CM.

grown in DMEM which is a protein rich culture medium as compared to MEM, the medium used for A431 cells. High protein concentration can result in higher adsorption of proteins on the NPs surface, preventing their aggregation and facilitating the endocytosis process. In another study comparing NPs behaviors in DMEM and RPMI, two intensely used culture media, DMEM induced a more abundant and stable protein corona on different sizes of gold NPs as compared to RPMI [28]. When the concentration of GNPs is high, the receptors will be able to receive NPs faster and easier, leading to shorter wrapping times and higher uptake into the cell. The conclusion would be that in order to obtain better uptake of GNPs into cells one should use the appropriate NPs size in combination with optimum incubation time and concentration as was demonstrated by Trono et al. [25]

TEM examinations revealed that GNPs-CM entered both types of cells by endocytosis, but displaying different behavior. On one hand, in the HaCaT cells the GNPs were found packed in vesicles in various regions of the cytoplasm and as membrane-free clusters, respectively. This double presence of the GNPs indicated an endocytosis process, followed in short time by disruption of the vesicles' membranes. The GNPs were thus released into the cytosol, but they still remained closely packed. On the other hand, in the malignant cells the GNPs-CM were observed only grouped in clusters within the cytosol. But, despite the fact that we could not observe endocytic vesicles with GNPs, one may assume that their internalization occurred by a similar import mechanism of endocytosis as in the $\mathrm{HaCaT}$ cells. This assumption is sustained by the aggregation of GNPs indicating the recent disruption of the vesicles' membrane. Moreover, the absence of the endocytic vesicles, corroborated with the presence of the GNPs grouped in clusters in the vicinity of the plasma membrane, indicated a more sensitive and labile membrane of the carcinoma cells, releasing the GNPs-CM into the cytosol immediately after their uptake. In both cases GNPs of various sizes were visualized inside the cells, suggesting that there was no size limitation in the endocytosis process. The adsorption of serum proteins facilitates the cellular uptake of these NPs by a mechanism called receptor mediated endocytosis, which has been proposed as the primary mechanism of cellular entry [29]. NPs size was found to play a critical role in both the rate and extent of cellular uptake: $50 \mathrm{~nm}$ transferrincoated GNPs were taken up by mammalian cells at higher rates and extents compared to smaller and larger sizes (in the range of 10-100 nm) [30]. The explanation of this optimal size was based on the so-called "wrapping effect," which describes how a cellular membrane encloses NPs [31].

GNPs-CM induced toxicity in both cell lines only at high concentrations, above $20 \mu \mathrm{g} / \mathrm{mL}$. HaCaT cells were more affected, probably as a result of a higher uptake in this cell line. The NPs synthesized with CM extract were significantly less toxic than GNPs synthesized with citrate, probably as a result of their different synthesis methods. The mean diameter of GNPs-CM was $12.079 \pm 3.588 \mathrm{~nm}$, which was in the range of sizes that were not cytotoxic in several experiments made by other research groups $[32,33]$. However, other studies found that GNPs were cytotoxic: citrate gold nanospheres of $13.1 \mathrm{~nm}$ decreased cell proliferation rate, adhesion, and motility of human dermal fibroblasts [34]. The controversial results obtained in different studies can be attributed to differences in the study design involving dosages, surface chemistry, cell types, and so forth.

The most important factors involved in NP-induced oxidative stress are the oxidative properties of the NPs themselves and the generation of ROS upon interaction of NPs with the cellular material. The direct prooxidant effects of NPs are due to their physicochemical properties including surface reactivity, particle size, and surface charge [35]. GNPs-CM did not induce significant ROS production in the treated 


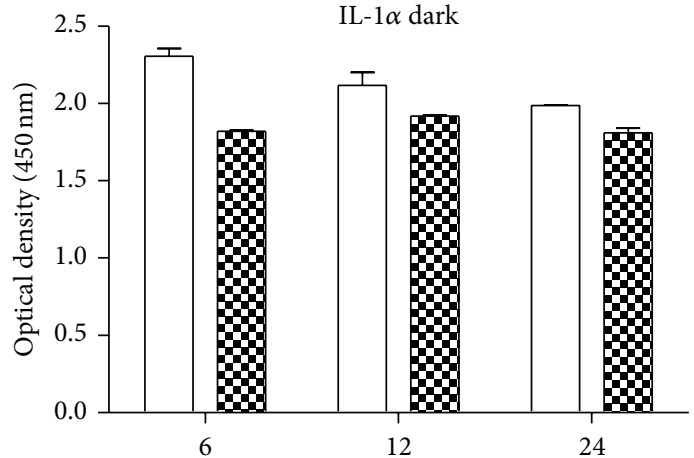

(h)
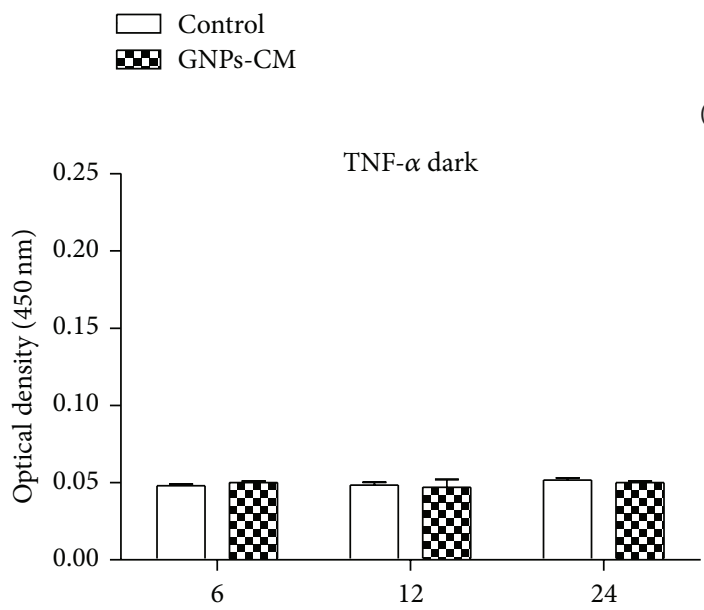

(h)

Control

ㅁom AuNP CM

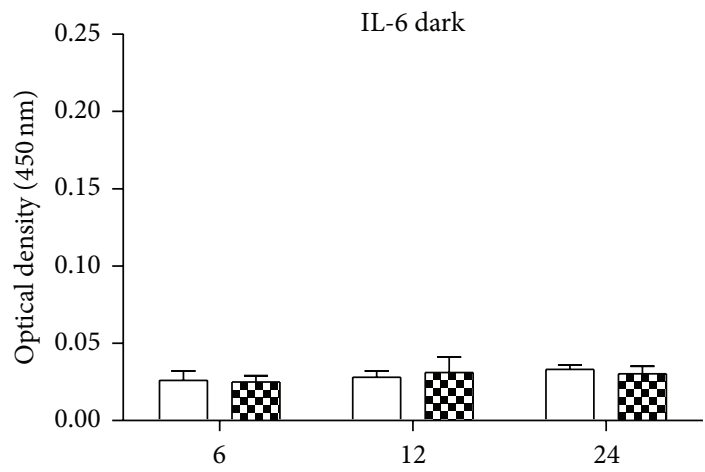

(h)

Control

$\square$ AuNP CM

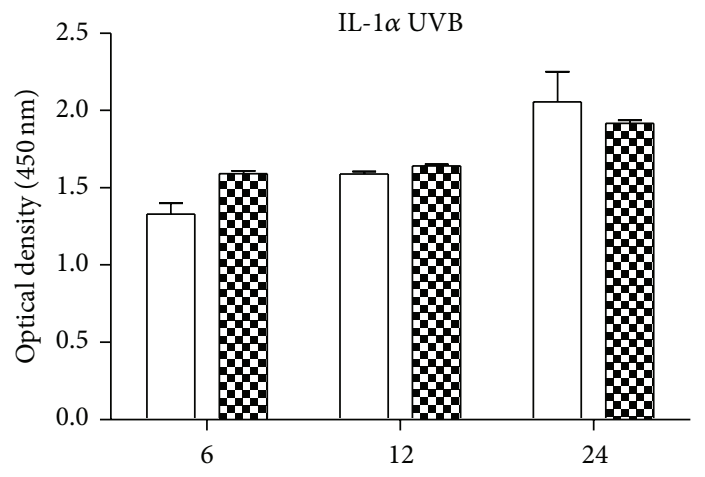

(h)
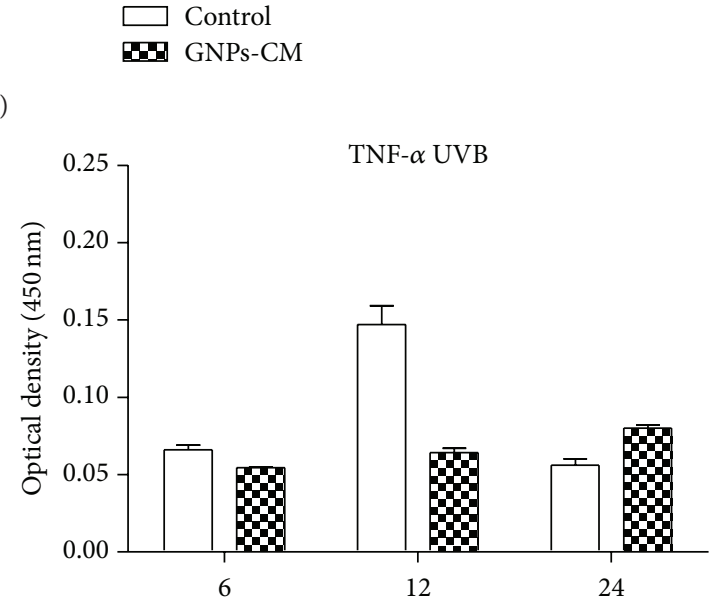

(h)

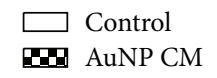

(b)

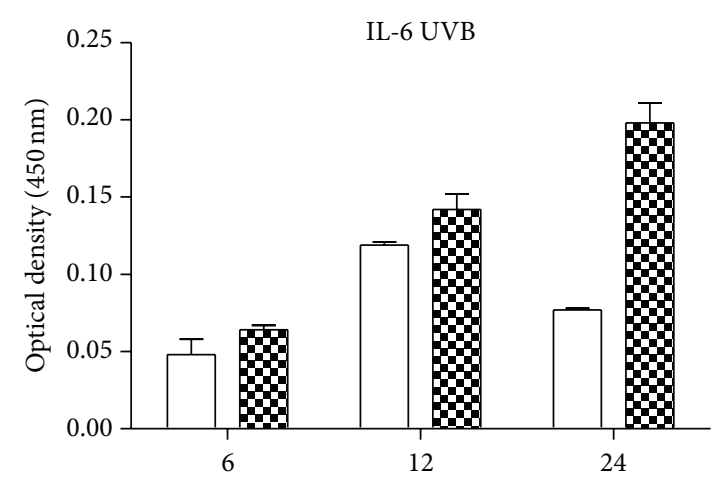

(h)

(c)

FIGURE 9: Inflammatory cytokine levels in HaCaT cells' culture medium following treatment with GNPs-CM (6 $\mu \mathrm{g} / \mathrm{mL}$ ). (a) IL-1 $\alpha$ secretion by HaCaT cells treated with GNPs-CM (dark) shows no modification in this cytokines' secretion at neither time point; the treatment with gold NPs before UVB irradiation has no significant influence on IL- $1 \alpha$ synthesis. The presence of gold NPs has no influence on IL-1 $\alpha$ synthesis after irradiation; (b) TNF- $\alpha$ levels after 6, 12, and $24 \mathrm{~h}$ incubation with GNPs-CM show no differences compared to control cells (dark). Irradiation only (UVB) results in significantly higher TNF- $\alpha$ levels at the $12 \mathrm{~h}$ time point, while the presence of GNPs-CM reduces TNF- $\alpha$ secretion to the levels found in nonirradiated cells; (c) IL-6 secretion is not affected by GNPs-CM (dark); UVB exposure increases IL6 release, mostly at $12 \mathrm{~h}$ after exposure; GNPs-CM treatment increases IL-6 levels in irradiated cells, mostly at $24 \mathrm{~h}$. 
cells compared to control cells with one exception, when the highest concentration $(15 \mu \mathrm{g} / \mathrm{mL})$ of NPs is used on $\mathrm{HaCaT}$ cells after $8 \mathrm{~h}$ incubation. This could be the result of the higher uptake of GNPs-CM in HaCaT cells compared to A431 cells, leading to higher production of ROS and thus higher cytotoxicity.

GNPs-CM proved not to produce additional DNA lesions after incubation with $\mathrm{HaCaT}$ and A431 cells. These results are similar to those obtained by Schulz et al. [36] who tested GNPs with different sizes, $2 \mathrm{~nm}, 20 \mathrm{~nm}$, and $200 \mathrm{~nm}$, administered by single dose intratracheal instillation in rats. They performed alkaline comet assay and micronucleus test and found no increase in relative tail intensity and no increase in $\mathrm{MN}$ formation. Also Khan et al. found no cytotoxicity and changes in gene expression patterns after the administration of $18 \mathrm{~nm}$ spherical GNPs with citrate to HeLa cells [37].

Nanoparticles can also interact with the host's immune system, and this effect can be useful or harmful, depending on the purpose of the NPs administration. This is why it is important to establish if a newly synthesized nanomaterial has a potential effect on the immune system and thus the levels of cytokines, especially proinflammatory cytokines which could be used as biomarkers of immunotoxicity [38, 39]. Immunotoxicity is usually associated with cytotoxicity, adverse reactions, and thus low efficacy. Keratinocytes, the main epidermal cell, function as a major contributor to cytokine production. Of the primary cytokines, IL- $1 \alpha$ predominates, being constitutively synthesized as a biologically active precursor protein (proIL- $1 \alpha)$. IL- $1 \alpha$ remains cell associated in keratinocytes and its biological activity, which involves wound healing and leukocyte recruitment, is regulated through its cell-expressed surface receptors. In our study, after UVB irradiation $\left(100 \mathrm{~mJ} / \mathrm{cm}^{2}\right)$, IL- $1 \alpha$ levels in the supernatants of irradiated cells decreased after $6 \mathrm{~h}$, increasing gradually at 12 and $24 \mathrm{~h}$ to the same levels as in control cells, which is consistent with the results of Magcwebeba et al. [40]. GNPs$\mathrm{CM}$ incubated with $\mathrm{HaCaT}$ cells (in the dark) did not affect the secretion of inflammatory cytokines IL- $1 \alpha$, IL- 6 , and TNF- $\alpha$. TNF- $\alpha$, a cytokine which is inducible upon exposure to stimuli, occurs at very low levels in cultured keratinocytes and seems to play a lesser role regarding inflammation in vivo when compared to IL-1 [41]. In HaCaT cells irradiated with UVB the presence of GNPs-CM reduced the level of TNF- $\alpha$ as compared to the cells exposed to irradiation only. This behavior could be interpreted as an anti-inflammatory effect of the NPs. IL-6 secretion after UVB was additionally augmented at all intervals by the presence of NPs. IL- 6 is a cytokine which activates Jak-stat signaling pathway having both pro- (stimulation of B and T lymphocytes, stimulation of chemokines, and adhesion molecules expression on endothelial cells) and anti-inflammatory (inhibition of macrophages and fibroblasts, inhibition of IL-12, IFN- $\gamma$, and proteases, etc.) actions [42]. The specific role of IL-6 in a particular inflammatory process could be determined by the balance between the proand anti-inflammatory effects on different cell types. In our case the additional increase of IL- 6 after UVB irradiation in the cells treated with GNPs-CM could also be regarded as an anti-inflammatory effect of the GNPs.

\section{Conclusion}

Gold nanoparticles synthesized with a polyphenols-rich extract from Cornus mas fruits were uptaken by $\mathrm{HaCaT}$ and A431 cells, where they had low toxicity and minimal ROS production and did not induce additional DNA lesions or an increase of inflammatory cytokines production. When added to the cells treated with UVB radiation, GNPs-CM had anti-inflammatory effect, modulating the secretion of specific cytokines. All these properties, along with an easy and affordable method of synthesis, make them suitable candidates for future applications in cosmetics and dermatology.

\section{Competing Interests}

The authors declare that they have no conflict of interests.

\section{Acknowledgments}

This work was supported by the Ministry of Education, Research, Youth and Sports, Romania, as a part of the Research Project no. 147/2012 PN-II-PT-PCCA-2011-3-10914.

\section{References}

[1] P. Ghosh, G. Han, M. De, C. K. Kim, and V. M. Rotello, "Gold nanoparticles in delivery applications," Advanced Drug Delivery Reviews, vol. 60, no. 11, pp. 1307-1315, 2008.

[2] R. Popovtzer, A. Agrawal, N. A. Kotov et al., "Targeted gold nanoparticles enable molecular CT imaging of cancer," Nano Letters, vol. 8, no. 12, pp. 4593-4596, 2008.

[3] D. Pissuwan, S. M. Valenzuela, and M. B. Cortie, "Therapeutic possibilities of plasmonically heated gold nanoparticles," Trends in Biotechnology, vol. 24, no. 2, pp. 62-67, 2006.

[4] T. Stuchinskaya, M. Moreno, M. J. Cook, D. R. Edwards, and D. A. Russell, "Targeted photodynamic therapy of breast cancer cells using antibody-phthalocyanine-gold nanoparticle conjugates," Photochemical and Photobiological Sciences, vol. 10, no. 5, pp. 822-831, 2011.

[5] J. Conde, G. Doria, and P. Baptista, "Noble metal nanoparticles applications in cancer," Journal of Drug Delivery, vol. 2012, Article ID 751075, 12 pages, 2012.

[6] L. Smith, Z. Kuncic, K. Ostrikov, and S. Kumar, "Nanoparticles in cancer imaging and therapy," Journal of Nanomaterials, vol. 2012, Article ID 891318, 7 pages, 2012.

[7] I. J. La Plante, T. W. Zeid, P. Yang, and T. Mokari, "Synthesis of metal sulfide nanomaterials via thermal decomposition of single-source precursors," Journal of Materials Chemistry, vol. 20, no. 32, pp. 6612-6617, 2010.

[8] G. M. Sulaiman, W. H. Mohammed, T. R. Marzoog, A. A. A. Al-Amiery, A. A. H. Kadhum, and A. B. Mohamad, "Green synthesis, antimicrobial and cytotoxic effects of silver nanoparticles using Eucalyptus chapmaniana leaves extract," Asian Pacific Journal of Tropical Biomedicine, vol. 3, no. 1, pp. 58-63, 2013.

[9] L. Sintubin, W. Verstraete, and N. Boon, "Biologically produced nanosilver: current state and future perspectives," Biotechnology and Bioengineering, vol. 109, no. 10, pp. 2422-2436, 2012. 
[10] S. Tural and I. Koca, "Physico-chemical and antioxidant properties of cornelian cherry fruits (Cornus mas L.) grown in Turkey," Scientia Horticulturae, vol. 116, no. 4, pp. 362-366, 2008.

[11] N. Ersoy, Y. Bagci, and V. Gok, "Antioxidant properties of 12 cornelian cherry fruit types (Cornus mas L.) selected from Turkey," Scientific Research and Essays, vol. 6, no. 1, pp. 98-102, 2011.

[12] J. Krisch, L. Galgóczy, M. Tölgyesì, T. Papp, and C. Vágvölgyi, "Effect of fruit juices and pomace extracts on the growth of Gram-positive and Gram-negative bacteria," Acta Biologica Szegediensis, vol. 52, no. 2, pp. 267-270, 2008.

[13] B. Yousefi, M. Abasi, M. M. Abbasi, and R. Jahanban-Esfahlan, "Anti-proliferative properties of Cornus mass fruit in different human cancer cells," Asian Pacific Journal of Cancer Prevention, vol. 16, no. 14, pp. 5727-5731, 2015.

[14] M. M. Giusti and R. E. Wrolstad, "Characterization and measurement of anthocyanins by UV-visible spectroscopy," in Current Protocols in Food Analytical Chemistry, R. E. Wrolstad, Ed., chapter 1-2, pp. 19-32, John Wiley \& Sons, New York, NY, USA, 2001.

[15] V. L. Singleton, R. Orthofer, and R. M. Lamuela-Raventós, "Analysis of total phenols and other oxidation substrates and antioxidants by means of Folin-Ciocalteu reagent," Methods in Enzymology, vol. 299, pp. 152-178, 1999.

[16] M. Crisan, L. David, B. Moldovan et al., "New nanomaterials for the improvement of psoriatic lesions," Journal of Materials Chemistry B, vol. 1, no. 25, pp. 3152-3158, 2013.

[17] C. Berghian-Grosan, L. Olenic, G. Katona, M. Perde-Schrepler, and A. Vulcu, "L-Leucine for gold nanoparticles synthesis and their cytotoxic effects evaluation," Amino Acids, vol. 46, no. 11, pp. 2545-2552, 2014.

[18] I. Brie, M. Perde, P. Virág et al., "Relationship between tumor cells' in vitro radiosensitivity measured by comet assay and clinical response to radiotherapy of cervix carcinomas," Radioterapie \& Oncologie Medicala, vol. 2, pp. 96-105, 2005.

[19] V. M. Nagy and I. C. Brie, "Testul cometei”" in Predictia Radiosensibilitatii Cancerului de Col Uterin: Implicatii Terapeutice, pp. 93-108, Universitatea de Medicină și Farmacie Iuliu Hațieganu, Cluj-Napoca, Romania, 2009.

[20] P. K. Jain, X. Huang, I. H. El-Sayed, and M. A. El-Sayed, "Noble metals on the nanoscale: optical and photothermal properties and some applications in imaging, sensing, biology, and medicine," Accounts of Chemical Research, vol. 41, no. 12, pp. 1578-1586, 2008

[21] J. R. Antonio, C. R. Antônio, I. L. Soares-Cardeal, J. M. A. Ballavenuto, and J. R. Oliveira, "Nanotechnology in dermatology," Anais Brasileiros de Dermatologia, vol. 89, no. 1, pp. 126136, 2014.

[22] A. Hastings, Investigating the immunotoxicology of silver nanoparticles in vitro [Ph.D. thesis], School of Medical Sciences, College of Science, Engineering and Health, RMIT University, 2012, https://researchbank.rmit.edu.au/eserv/rmit:160329/Wright .pdf.

[23] Y. Pan, S. Neuss, A. Leifert et al., "Size-dependent cytotoxicity of gold nanoparticles," Small, vol. 3, no. 11, pp. 1941-1949, 2007.

[24] P. N. Njoki, I.-I. S. Lim, D. Mott et al., "Size correlation of optical and spectroscopic properties for gold nanoparticles," The Journal of Physical Chemistry C, vol. 111, no. 40, pp. 14664-14669, 2007.
[25] J. D. Trono, K. Mizuno, N. Yusa, T. Matsukawa, K. Yokoyama, and M. Uesaka, "Size, concentration and incubation time dependence of gold nanoparticle uptake into pancreas cancer cells and itsfuture application to X-ray drug delivery system," Journal of Radiation Research, vol. 52, no. 1, pp. 103-109, 2011.

[26] G. Maiorano, S. Sabella, B. Sorce et al., "Effects of cell culture media on the dynamic formation of protein-nanoparticle complexes and influence on the cellular response," ACS Nano, vol. 4, no. 12, pp. 7481-7491, 2010.

[27] H. K. Patra, S. Banerjee, U. Chaudhuri, P. Lahiri, and A. K. Dasgupta, "Cell selective response to gold nanoparticles," Nanomedicine: Nanotechnology, Biology, and Medicine, vol. 3, no. 2, pp. 111-119, 2007.

[28] M. Rahman, S. Laurent, N. Tawil, L. Yahia, and M. Mahmoudi, "Nanoparticle and protein corona," in Protein-Nanoparticle Interactions: The Bio-Nano Interface, vol. 15 of Springer Series in Biophysics, pp. 21-44, 2013.

[29] B. D. Chithrani and W. C. W. Chan, "Elucidating the mechanism of cellular uptake and removal of protein-coated gold nanoparticles of different sizes and shapes," Nano Letters, vol. 7, no. 6, pp. 1542-1550, 2007.

[30] B. D. Chithrani, A. A. Ghazani, and W. C. W. Chan, "Determining the size and shape dependence of gold nanoparticle uptake into mammalian cells," Nano Letters, vol. 6, no. 4, pp. 662-668, 2006.

[31] A. M. Alkilany and C. J. Murphy, "Toxicity and cellular uptake of gold nanoparticles: what we have learned so far?" Journal of Nanoparticle Research, vol. 12, no. 7, pp. 2313-2333, 2010.

[32] E. E. Connor, J. Mwamuka, A. Gole, C. J. Murphy, and M. D. Wyatt, "Gold nanoparticles are taken up by human cells but do not cause acute cytotoxicity," Small, vol. 1, no. 3, pp. 325-327, 2005.

[33] R. Shukla, V. Bansal, M. Chaudhary, A. Basu, R. R. Bhonde, and M. Sastry, "Biocompatibility of gold nanoparticles and their endocytotic fate inside the cellular compartment: a microscopic overview," Langmuir, vol. 21, no. 23, pp. 10644-10654, 2005.

[34] N. Pernodet, X. Fang, Y. Sun et al., "Adverse effects of citrate/gold nanoparticles on human dermal fibroblasts," Small, vol. 2, no. 6, pp. 766-773, 2006.

[35] A. Manke, L. Wang, and Y. Rojanasakul, "Mechanisms of nanoparticle-induced oxidative stress and toxicity," BioMed Research International, vol. 2013, Article ID 942916, 15 pages, 2013.

[36] M. Schulz, L. Ma-Hock, S. Brill et al., "Investigation on the genotoxicity of different sizes of gold nanoparticles administered to the lungs of rats," Mutation Research/Genetic Toxicology and Environmental Mutagenesis, vol. 745, no. 1-2, pp. 51-57, 2012.

[37] J. A. Khan, B. Pillai, T. K. Das, Y. Singh, and S. Maiti, "Molecular effects of uptake of gold nanoparticles in HeLa cells," ChemBioChem, vol. 8, no. 11, pp. 1237-1240, 2007.

[38] M. Elsabahy and K. L. Wooley, "Cytokines as biomarkers of nanoparticle immunotoxicity," Chemical Society Reviews, vol. 42, no. 12, pp. 5552-5576, 2013.

[39] P. Virag and V. I. Cernea, "Clasificarea citokinelor," in Factori de Crestere Hematopoietici cu Implicatii in Oncologie, pp. 29-42, Universitatea de Medicină şi Farmacie Iuliu Hațieganu, ClujNapoca, Romania, 2008.

[40] T. Magcwebeba, S. Riedel, S. Swanevelder, P. Bouic, P. Swart, and W. Gelderblom, "Interleukin-1 $\alpha$ induction in human keratinocytes (HaCaT): an in vitro model for chemoprevention in 
skin," Journal of Skin Cancer, vol. 2012, Article ID 393681, 10 pages, 2012.

[41] C. S. Newby, R. M. Barr, M. W. Greaves, and A. I. Mallet, "Cytokine release and cytotoxicity in human keratinocytes and fibroblasts induced by phenols and sodium dodecyl sulfate," Journal of Investigative Dermatology, vol. 115, no. 2, pp. 292-298, 2000.

[42] S. T. Ahmed and L. B. Ivashkiv, "Inhibition of IL-6 and IL10 signaling and Stat activation by inflammatory and stress pathways," The Journal of Immunology, vol. 165, no. 9, pp. 5227$5237,2000$. 

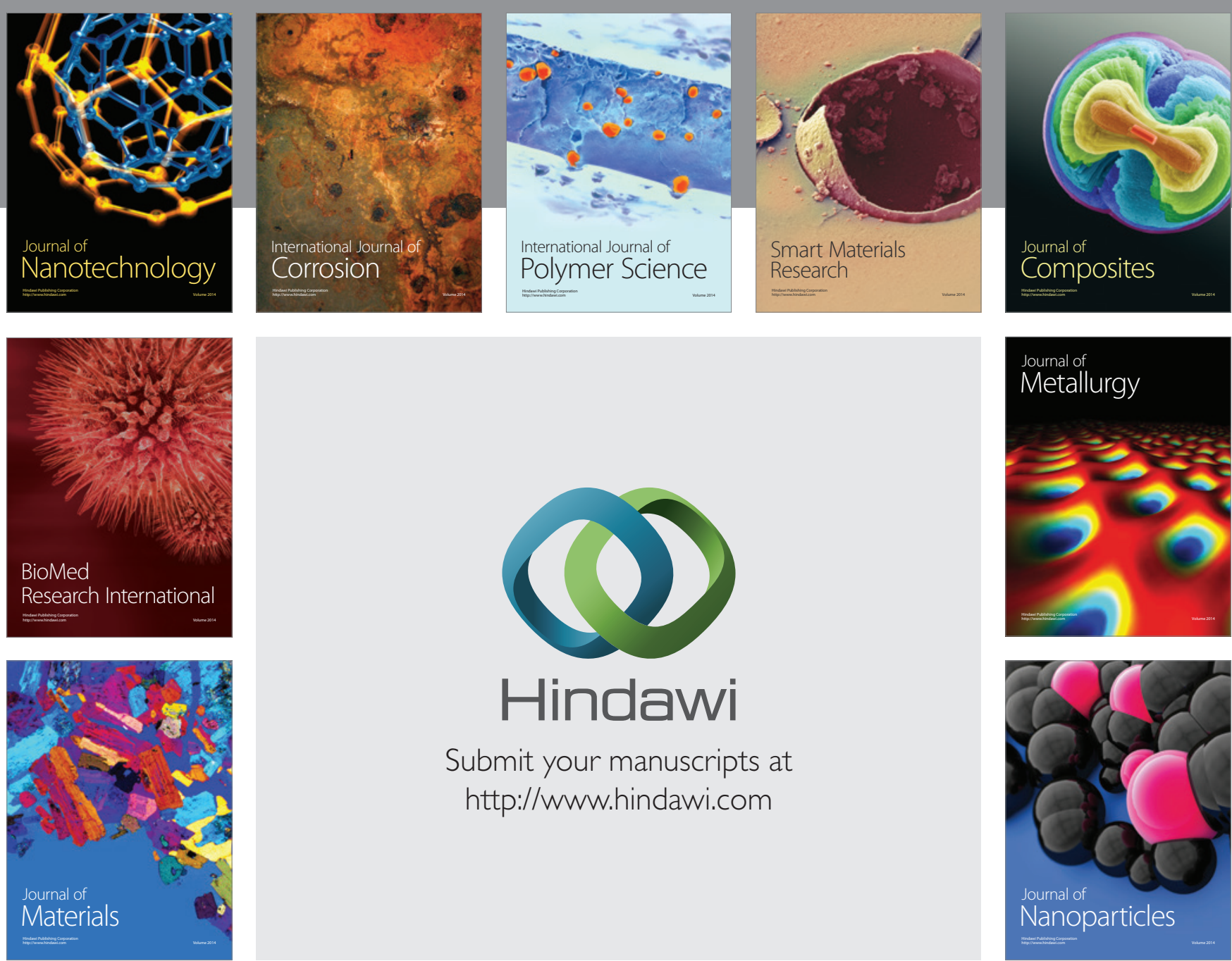

\section{Hindawi}

Submit your manuscripts at

http://www.hindawi.com

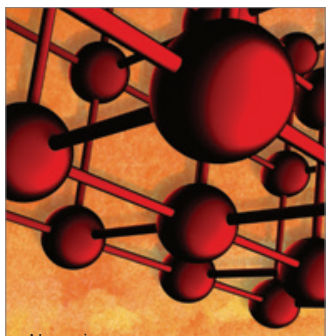

Materials Science and Engineering
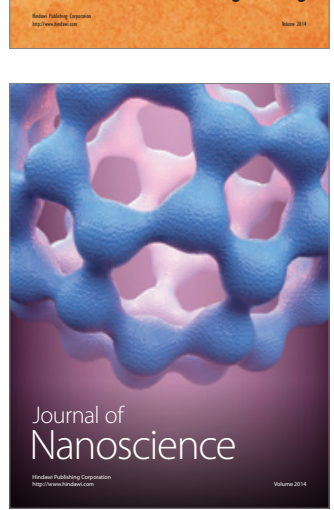
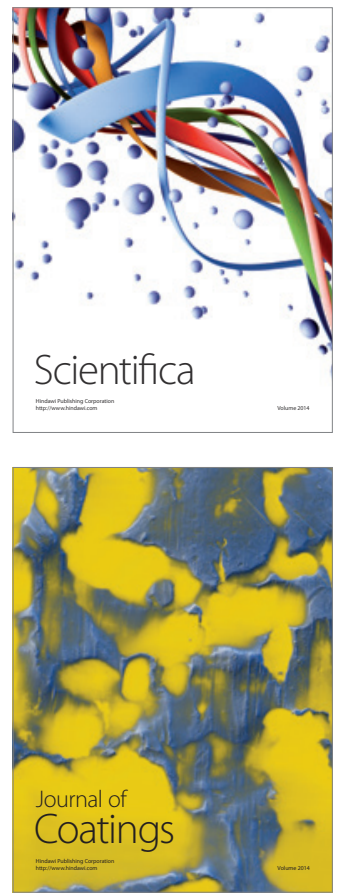
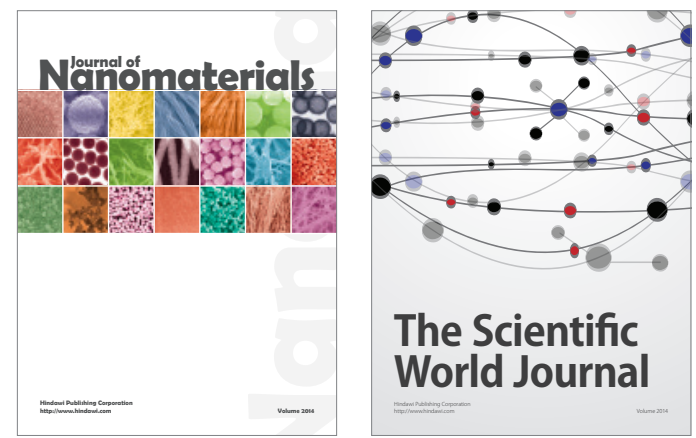

The Scientific World Journal
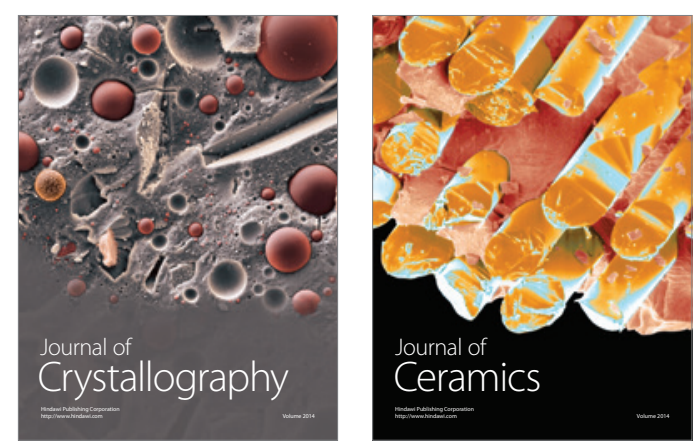
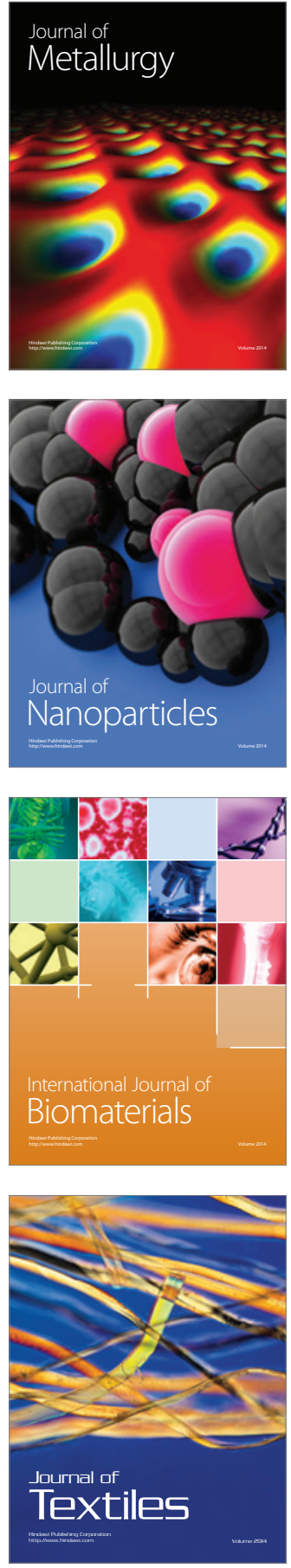